\title{
Combating Academic Corruption and Enhancing Academic Integrity through International Accreditation Standards: The Model of Qatar University
}

\author{
Mohamed Y. Mattar ${ }^{1} \mathbb{D}$
}

Accepted: 18 January 2021 / Published online: 17 April 2022

(c) The Author(s) 2021

\begin{abstract}
Academic institutions aim at achieving the highest standards of education and learning. Consequently, they prohibit academic corruption such as cheating or plagiarism. This article examines how international accreditation and quality assurance standards embody academic integrity as a main factor in deciding whether an academic institution should be accredited, and what ranking should an academic institution acquire in a competitive contest for educational excellence. Academic integrity is broadly defined to include, in addition to cheating and plagiarism, compliance with standards of human rights, labor rights, corporate social responsibility, ant-corruption measures, environmental protection, social media usage, protection of underage students, anti-radicalization and extremism, avoidance of conflict of interest, faculty professionalism, students codes of conduct and human experimentation. Academic institutions should adopt policies that are designed to address these diverse standards and accommodate diversity and enhance access to education for all without discrimination. Academic institutions should also strictly require the highest standards in teaching and research. This article will discuss the different policies, laws, rules and regulations adopted by Qatar University as a model for incorporating academic integrity, which may be of interest to the international higher education community. This article will ask two main questions; are accrediting institutions asking the right questions to find out whether an academic institution strictly adheres to a policy of academic integrity, and whether policies adopted by academic institutions, Qatar University as a model, are adequate to address various violations of academic integrity.
\end{abstract}

Keywords Academic corruption · Academic integrity · International accreditation · Quality assurance · Qatar university

Mohamed Y. Mattar

mmattar@qu.edu.qa

1 Clinical Professor of Law and Chair of the Legal Skills Department, Qatar University College of Law, P. O. Box, 2713 Doha, Qatar 


\section{Introduction}

Academic corruption ${ }^{1}$ is a common phenomenon in almost every university in the world. ${ }^{2}$ Arab Universities are no exception. ${ }^{3}$ The World Bank defines corruption as "the abuse of public office for private gain." Whether this definition applies to academic corruption depends on whether we consider education as a public good. ${ }^{4}$

Article 13 of the United Nations Convention Against Corruption calls upon States "to promote the active participation of individuals and groups outside the public sector, such as civil society, non-governmental organizations and community-based organizations, in the prevention of and the fight against corruption and to raise public awareness regarding the existence, causes and gravity of and the threat posed by corruption". Article (13) (c) of the Convention states that such participation should be strengthened by measures such as "Undertaking public information activities that contribute to non-tolerance of corruption, as well as public education programmes, including schools and university curricula."

To what extent does Qatar University, as a model which may be of interest to the international higher education community, incorporate non-tolerance of academic corruption in the university curricula in its policies, procedures, rules and regulations?

It has been held by the highest court in Qatar that an employer may dismiss the worker without notice and without payment of the end of employment compensation if the employee submits false certificates or documents. ${ }^{5}$ In this case, the employee submitted a doctorate degree that he claimed that he received from "Hatford" university in the U.S., while there was no university that carried this name and the employee failed to provide evidence otherwise. The employee was hired based upon his status as a holder of a doctorate degree which in fact did not exist. This is an apparent example of misrepresentation of qualifications and credentials, a case of corruption that may be

\footnotetext{
1 This research was conducted within the framework of a research project funded by the Qatar National Research Fund (QNRF)—National Priorities Research Program (NPRP)—Cycle 11—Qatar Foundation. The research project is entitled "Toward Reforming the Economic Legislative Mechanisms for Achieving Legal Security in light of the National Policies of the State of Qatar"-NPRP11S-0101-180,160. This research is part of the research papers related to the output of this three-year research project (2019-2022).

2 See e.g. Alogali, A. (2015). Innovation with Integrity: Exploring Academic Honesty and Intellectual Property in the Middle East. In WEI International Academic Conference proceedings. University Affiliation: University of Rochester, Rochester NY, USA. https://www.westeastinstitute.com/wp-content/uploads/ 2015/07/Azizah-Alogali.pdf., Griffith, J. (2013). Pedagogical over Punitive: The Academic Integrity Websites of Ontario Universities. Canadian journal of higher education, 43(1), 1-22. Abusafia, A. H., Roslan, N. S., Yusoff, D. M., \& Nor, M. Z. M. (2018). Snapshot of academic dishonesty among Malaysian nursing students: A single university experience. Journal of Taibah University medical sciences, 13(4), 370-376, Namagembe, S., \& Ntayi, J. M. (2012). Ethical sensitivity, academic dishonesty and career growth of academic staff in institutions of higher learning in Uganda. International Journal of Economics and Management Sciences, 1(8), 56-63., Feday, S. W. (2017). Academic dishonesty in Ethiopian higher education and its implication for corruption. Beijing L. Rev., 8, 10. Razek, N. (2014). Academic integrity: A Saudi student perspective. Academy of Educational Leadership Journal, 18(1), Gina Cinali, Middle Eastern Perspectives of Academic Integrity: A view from the Gulf Region, Handbook of Academic Integrity 1-17 (2015).

${ }^{3}$ Badran, A., Baydoun, E., \& Hillman, J. R. (Eds.). (2019). Major challenges facing higher education in the Arab world: Quality assurance and relevance. Springer.

${ }^{4}$ See Nabaho, L., \& Turyasingura, W. (2019). Battling Academic Corruption in Higher Education: Does External Quality Assurance (EQA) Offer a Ray of Hope?. Higher Learning Research Communications, 9(1), 2.

5 In recognition of a university degree that has been obtained through correspondence only, see Qatar Supreme Court, Civil and Commercial circuit, case No. 81 of 2012.
} 
equally applicable to academic institutions if they fail to carefully and diligently review, examine and verify the qualifications and credentials of those who apply for an academic employment.

However, academic corruption is not limited to cheating or misrepresentation of qualifications and credentials. Since it was established, Qatar University awarded only two honorary doctorate degrees. Qatar University first honorary doctorate degree was awarded to Turkish President, Recep Tayyip Erdogan on December 2nd 2015. The Prime Minister of Malaysia, Mahathir bin Mohamad received the second honorary doctorate awarded by Qatar University in December 2019. As stated in Qatar University policy "Honorary Doctorate of Philosophy" degrees are awarded only to individuals with "extraordinary contributions", "who merit special recognition of outstanding leadership and/or achievement in a field consistent with the university values." This policy is designed to preserve academic integrity.

Absence of academic integrity, ${ }^{6}$ corruption, dishonesty, misconduct or malpractice include many forms including misrepresentation of qualifications and credentials, cheating, ${ }^{7}$ multiple submissions ${ }^{8}$ plagiarism ${ }^{9}$, or any other act that is inconsistent with the mission of an academic institution in providing the highest standards of education and learning. For the purposes of this Article, I broadly define academic integrity to include compliance with standards of human rights, labor rights, corporate social responsibility, anti-corruption measures, environmental protection, social media usage, protection of underage students, anti-radicalization and extremism, avoidance of conflict of interest, faculty professionalism, students codes of conduct and human experimentation. Academic

\footnotetext{
6 The term academic integrity was first used by Donald McCabe. See generally, Klemenčič, M. (2019). 20 Years of the Bologna Process in a Global Setting: the external dimension of the Bologna Process revisited. In European higher education area: The impact of past and future policies (pp. 61-75). Springer, Cham. Curaj, A., Deca, L., \& Pricopie, R. (2018). European higher education area: The impact of past and future policies (p. 721). Springer Nature. See also, Dimkpa, D. I. (2011). Prevalence, causes and effects of academic corruption in Rivers State Universities, Nigeria. Makerere Journal of Higher Education, 3(1), 33-44., Osipian, A. L. (2007). Corruption in higher education: Conceptual approaches and measurement techniques. Research in Comparative and International Education, 2(4), 313-332.

7 Cheating is "obtaining, using or attempting to use unauthorized materials or information (for example, notes, texts, or study aids) or help from another person (for example, looking at another student's test paper, or communicating with others during an exam via talking, notes, texts, electronic devices or other study aids), in any work submitted for evaluation for academic credit. This includes exams, quizzes, laboratory assignments, papers, presentations, and/or other assignments, other examples include altering a graded work after it has been returned, then submitting the work for re-grading, unauthorized collaboration on an academic assignment, or submitting identical or highly similar papers for credit in more than one course without prior permission from the course instructors.", Code of Academic Integrity, Aurora University, Illinois, U.S, https://www.aurora.edu/academics/resources/code.html.

8 "It is a violation of academic honesty to submit substantial portions of the same work for credit more than once without the explicit consent of the faculty member(s) to whom the material is submitted for additional credit. In case in which there is a natural development of research or knowledge in a sequence of courses, use of prior work may be desirable, even required; however, the student is responsible for indicating in writing, as a part of such use, that the current work submitted for credit is cumulative in nature.", Georgia State University Code of Conduct and Administrative Policies (June 2019) Page 17. See link at: https:// codeofconduct.gsu.edu/

9 Plagiarism is defined as "Presenting someone else's work, including the work of other students, as one's own. Any ideas or materials taken from another source for either written or oral use must be fully acknowledged, unless the information is common knowledge, what is considered "common knowledge" may differ from course to course.,

[Code of Student Rights, Responsibilities and Conduct, Indiana University.] https://studentcode.iu.edu/?_ $\mathrm{ga}=2.66081709 .2018066908 .1591548928-1456551481.1591548928$
} 
institutions should adopt policies that are designed to accommodate diversity and enhance access to education for all without discrimination.

Academic Integrity, as such, should be incorporated in the factors that measure the reputation of an academic institution and determines its ranking. It has been argued that "A ranking methodology or scheme that principally focuses on academic integrity indicators ought to be explored by quality assurance agencies in national higher education systems. Such ranking schemes can act as an incentive for higher education institutions to improve their academic integrity standing. Poor ranking on the integrity front can occasion enormous reputation damages to institutions and act as disincentive for students to enroll at the institutions." ${ }^{10}$ It has also been asserted that "Accreditation has the potential to reduce incidents of academic corruption." 11

\section{Research Question}

This article will examine academic corruption and academic integrity by addressing two main questions: First: To what extent are academic accreditation and quality assurance standards designed to improve academic integrity and reduce academic corruption and whether in fact they assist academic institutions in achieving this goal? Second: What are the policies, procedures, rules and regulations that a university, such as Qatar University, put in place to combat academic corruption and enhance academic integrity and whether they may serve as a model for Arab universities in the region? Do they mirror the international standards of quality assurance and academic accreditation? Are there any omissions and gaps that must be reviewed and remedied?

Neither of these major issues has been adequately addressed. As has been observed "most current quality assurance methods are unlikely to uncover academic corruption" and "additional steps to address academic corruption" are needed including to "make explicit the commitment to reducing corruption." 12 It has also been noted that there is lack of "welldefined policies that make clear how unethical behavior is defined and how infractions will be addressed." ${ }^{\prime 13}$ I will attempt to address these two arguments.

\section{Methodology}

This article adopts a descriptive and analytical analysis of the two principle issues of focus. The article will cover the different accrediting agencies and how do they incorporate academic integrity as a main factor in deciding whether an academic institution should be granted accreditation. Then the article will analyze the policies adopted by Qatar University and how they adequately and effectively address academic integrity. The article will identify

\footnotetext{
${ }^{10}$ Nabaho, L., \& Turyasingura, W. (2019). Battling Academic Corruption in Higher Education: Does External Quality Assurance (EQA) Offer a Ray of Hope?. Higher Learning Research Communications, 9(1), 2.

11 Id at 6.

12 See, Eaton, J. S. (2020). "Combatting Academic Corruption". In Corruption in Higher Education. Leiden, The Netherlands: Brill I Sense. https://doi.org/10.1163/9789004433885_026

13 See, Reisberg, L. (2020). "Challenges to Eradicating Academic Corruption". In Corruption in Higher Education. Leiden, The Netherlands: Brill I Sense. https://doi.org/10.1163/9789004433885_027
} 
omissions and gaps and suggest more comprehensive policies to achieve this goal. The article also relies on a questionnaire that has been sent to various accrediting agencies asking the following questions: 1 . To what extent is academic integrity a factor in granting accreditation? 2. What questions do you ask an academic institution to evaluate its level of academic integrity? 3. What policies would you consider as indicators of preservation of academic integrity? 4. What actions of an academic institution would signal in your judgement a case of academic corruption? 5. Do you include an explicit question on academic integrity? and 6. How do you define academic integrity? The answers that were received by the author will be utilized to further the arguments made throughout this research.

\section{Literature Review}

\section{Shifting the Focus From Student Cheating and Faculty Plagiarism to a Broader Concept of Academic Corruption}

Existing research focuses on student cheating and faculty plagiarism as the most obvious and common forms of academic corruption. This article adopts a wider scope of what constitutes academic corruption and addresses various issues including; corporate social responsibility standards, human rights policies, non discrimination in admissions, labor rights, verification of recruitment, an environmental policy, anti corruption measures and avoidance of conflict of interest, incorporating ethics in educational curricula, intellectual honesty, protection of intellectual property, policies, regulations and guidelines for research involving humans, professionalism of the faculty and students code of conduct. This approach is designed to unveil instances of academic corruption in an academic institution, whether these acts of corruption are committed by the students, the professors, the administrative staff or other third parties who are dealing with the university. This approach also emphasizes the core values that must be advanced by an academic institution such as respect for human rights and labor rights, observance of the principles of non discrimination and avoidance of conflict of interests and compliance with the rules of law pertaining to protection of children and protection of intellectual property rights...etc.

This is by no means a new approach. It has been argued that combating academic corruption should cover nine categories; corruption in higher education governance, corruption in the regulation of higher education, corruption in admissions and recruitment, corruption in assessment, corruption in credentials and qualifications, disparities in standards and values, misconduct in research and academic publishing and networking and communication to counter corruption. ${ }^{14}$

It has also been argued that educational corruption entails many forms including criminal act, tortious conduct, such as fraud or breach of fiduciary duty or "conduct that betrays the values that form the moral basis for the educational process, foremost among those being intellectual honesty."15

\footnotetext{
14 Glendinning, I. (2020). "The role of quality assurance and regulatory organizations to promote academic integrity," Chapters, in: Tracey Bretag (ed.), A Research Agenda for Academic Integrity, chapter 2, pages 13-27, Edward Elgar Publishing.).

15 Johnson, V. R. (2008). Corruption in Education: A Global Legal Challenge. Santa Clara Law Review, Vol. 48, 2008, Available at SSRN: https://ssrn.com/abstract=2891900
} 


\section{Writings on Quality Assurance and Academic Accreditation in the Arab Region}

Most writings on quality assurance and accreditation in higher education cover regions other than the Arab region, such as Russia and India. ${ }^{16}$ Intensive Research has also been conducted on universities in Latin America ${ }^{17}$ and Eastern Europe. ${ }^{18}$

To be sure, there have been early writings calling for the need for quality assurance in Arab academic institutions, including "integration of the quality assurance into the institution commitments, staff persuasion and engagement, commitment by each of the organizational units involved to ensure the quality in all of the services provided, and the development of a positive corporate culture." ${ }^{19}$ Some research have been done using samples from private universities in Lebanon ${ }^{20}$ or in the gulf region ${ }^{21}$ including Saudi Arabia. $^{22}$ These writings raised the importance of quality assurance and academic accreditation stating that "higher education institutions should adopt quality assurance and accreditation as an instrument to achieve goals to reach standards at global level., ${ }^{, 3}$

While focusing on cheating in Arab universities, several reasons have been advanced, including that grades are more important than learning for students, and that obtaining a degree is more necessary than acquiring knowledge or skills. ${ }^{24}$ In addition, references are made to an Arab culture of "fahlawa", an ability to achieve goals with minimal efforts and "wasta" or nepotism. ${ }^{25}$ Also contributing to cheating, the easy use of the internet ${ }^{26}$ and tolerance by the universities officials. ${ }^{27}$ Instances of academic corruption have been recorded in Arab universities, such as the famous 2019 investigation in four Lebanese

\footnotetext{
16 Denisova-Schmidt, Elena. Corruption in Higher Education. Leiden, The Netherlands: Brill I Sense, 2020. https://doi.org/10.1163/9789004433885 Web.

17 See e.g., Ayala-Enríquez, P., Franco-Pérez, N., Guerrero-Dib, J. G., \& Pizarro-Puccio, G. (2020). "From moral awareness to academic integrity in Latin America". In A Research Agenda for Academic Integrity. Cheltenham, UK: Edward Elgar Publishing. https://doi.org/10.4337/9781789903775.00009

18 Foltýnek, T., \& Dlabolová, D. (2020). "Academic integrity in Eastern Europe: beyond corruption and plagiarism". In A Research Agenda for Academic Integrity. Cheltenham, UK: Edward Elgar Publishing. https://doi.org/10.4337/9781789903775.00010)a

19 Elshobaky, Amel. (2005). Distance Higher Education in the Arab Region: The Need for Quality Assurance Frameworks. Online Journal of Distance Learning Administration. Volume VIII.

${ }^{20}$ McCabe, D.L., Feghali, T. \& Abdallah, H. Academic Dishonesty in the Middle East: Individual and Contextual Factors. Res High Educ 49, 451-467 (2008). https://doi.org/10.1007/s11162-008-9092-9

21 Cinali, G. (2016) Middle Eastern Perspectives of Academic Integrity: A View from the Gulf Region. In: Bretag T. (eds) Handbook of Academic Integrity. Springer, Singapore. https://doi.org/10.1007/978-981287-098-8_8

22 Razek, Nasser. (2014). ACADEMIC INTEGRITY: A SAUDI STUDENT PERSPECTIVE. Academy of Educational Leadership Journal. 18. 143-154.

23 Hamdatu, M. A. M., Siddiek, A. G., \& Rahman Al-Olyan, F. A. (2013). Application of Quality Assurance \& Accreditation in the Institutes of Higher Education in the Arab World ( Descriptive \& Analytical Survey). American International Journal of Contemporary Research, 3(4), 104-116.

${ }^{24}$ Razek, Nasser. (2014). ACADEMIC INTEGRITY: A SAUDI STUDENT PERSPECTIVE. Academy of Educational Leadership Journal. 18. 143-154.

25 Aljurf, Saladin \& Kemp, Linzi \& Williams, Paul. (2019). Exploring academic dishonesty in the Middle East: a qualitative analysis of students' perceptions. Studies in Higher Education. 1-13. 10.1080/03,075,07 9.2018.1564262.

${ }^{26}$ Khan, Z., \& Subramanian, S. (2012). Students go click, flick and cheat... e-cheating, technologies and more. Journal of Academic and Business Ethics, 6, 1-26. (conducting a survey on UAE universities).

27 Dodeen, Hamzeh M. (2012) Undergraduate Student Cheating in Exams. Damascus University Journal, Vol. 28, No (1) (Focusing on UAE universities).
} 
universities selling fake diplomas, It was alleged that bribes changed hands. 40 arrests were made. ${ }^{28}$

None of these writings, however inquire into the polices that must be adopted by Arab academic institutions to combat these instances of academic corruption and to put in place the appropriate response. I will analyze the policies of Qatar University as a model that may be followed by other universities in the region.

\section{A Need for a More Effective Quality Assurance and Academic Accreditation Programs in the Arab Region}

Quality assurance and academic accreditation of higher education in the Arab region is relatively new. ${ }^{29}$ It has been observed that the recent vast increase in higher education institutions was not accompanied by the proper and effective quality assurance programs. ${ }^{30}$ It has been stated that in Arab countries "the licensing of private and public universities can be strict, but follow-up monitoring is generally weak. So, for many degrees, universities have come to rely on European and American agencies to review the quality of educational programs. ${ }^{31}$ As has been noted "there is a need, therefore, to establish a strong regional accrediting body to define and maintain standards of art and designed education." 32 Seeking international accreditation from external agencies in Europe or the United States may also be motivated by "prestige". 33

It has also been established that "higher education institutions across the region need to focus on adopting and internalizing a culture of evaluation and accountability at every level among administrators, faculty, and students. Attention should be given to assessing teaching, program quality, and student outcomes. A standards-driven system is the only way to ensure that educational outcomes achieve individual and societal needs." 34

While an Arab Network for Quality Assurance and Higher Education (ANQAHE) was established in 2007, it has not been effective in monitoring quality assurance in the region. In the same year, the Arab Organization for Quality Assurance in Education (AROQA) was

\footnotetext{
${ }^{28}$ Denisova-Schmidt, E. (Eds.). (2020). Corruption in Higher Education. Leiden, The Netherlands: Brill I Sense. https://doi.org/10.1163/9789004433885

29 GANI, Abdul. (2009). "Quality Assurance of the Arab Open University in Saudi Arabia”. Asian Journal of Distance Education 7 (2).

30 Katherine Wilkens, Higher Education Reform in the Arab World, the U.S. Islamic World Forum papers, Washington: Brookings Press, 2011, p.34. 136).

31 Plackett, Benjamin \& Wachter, Sarah. An Arab Student's Guide to Higher-Education Accreditation. 6 June 2019. https://www.al-fanarmedia.org/2019/06/an-arab-students-guide-to-higher-education-accreditation/) see also, Faek, Rasha. How Arab Countries Regulate Quality in Higher Education. 20 September 2017. https:// www.chronicle.com/article/how-arab-countries-regulate-quality-in-higher-education/ (concluding that "after licensees are issues, government follow-up to check educational quality is usually weak or non-existent").

32 Sanaa Ashour \& Ahmed Said Ghonim I F. Robert Sabol (Reviewing Editor) (2017) The quest for regional accreditation of art and design education in the Arab Countries, Cogent Arts \& Humanities, 4:1, https://doi.org/10.1080/23311983.2017.1361639

33 Lynch, Sarah. A Growing Number of Arab Universities Seek International Accreditation. 15 March (2015). https://www.al-fanarmedia.org/2015/03/a-growing-number-of-arab-universities-seek-internationalaccreditation/

34 Katherine Wilkens, Higher Education Reform in the Arab World, the U.S. Islamic World Forum papers, Washington: Brookings Press, (2011), p.34. 136).
} 
established. The organization is limited to evaluating schools. The only university that has been accredited by the agency is Al-Janan University.

Lack of regional quality assurance and academic accreditation agencies has led Arab universities to seek international accreditation such as that granted by the Accreditation Board for Engineering and Technology $(\mathrm{ABET})^{35}$ and that granted by the Accreditation Council for Pharmacy Education - International Services Program (ACPE - ISP) and the German Accreditation Agency in Health and Social Sciences (AHPGS), ${ }^{36}$ and other international accreditation agencies that we will discuss in the following section.

\section{First: International Accreditation and Quality Assurance Standards on Academic Integrity}

International academic accreditation and quality assurance agencies are in consensus in incorporating academic Integrity in their evaluation and assessment of academic institutions and whether they meet the standards of quality education. "Commitment to Integrity in addition to academic freedom and institutional autonomy are highlighted as the main values adopted by the 2018 Bologna Process Implementation Report." ${ }^{37}$ The International Network of Quality Assurance Agencies for Higher Education (INQAAHE) ${ }^{38}$ recognizes as a key value that must be adopted in the practice of quality assurance, the "belief in the primacy of academic freedom and institutional integrity." In Asia, the Asia Pacific Quality Network (APQN) ${ }^{39}$ operates as a regional network for the purpose of enhancing the quality of higher education in association with the international Network for Quality Assurance Agencies in Higher Education (INQAAHE), "to promote good practice in the maintenance and improvement of quality in higher education in the Asia-Pacific region." 40 and "to enable members of APQN to alert to dubious accrediting practices and organizations." 41

\footnotetext{
$\overline{35}$ See, Marzouk, Osama. (2019). Status of ABET Accreditation in the Arab World. Global Journal of Educational Studies. 5. 1. 10.5296/gjes.v5i1.14218.).

${ }^{36}$ Alkhateeb FM, Arkle S, McDonough SLK, Latif DA. Review of National and International Accreditation of Pharmacy Programs in the Gulf Cooperation Council Countries. American Journal of Pharmaceutical Education. (2018) Dec;82(10):5980. https://doi.org/10.5688/ajpe5980.

${ }^{37}$ See, European Commission/ EACE/ Eurydice, 2018. The European Higher Education Area in 2018; Bologne Process Implementation Report, Luxembourg: Publication office of the European Union, The Bologne Declaration was signed in 1999 by ministers responsible for higher education from 29 European Countries. See generally, Marja Klemencic, 20 years of the Bologne Process in a Global setting: The External Dimensions of the Bologne Process Revisited, European Journal of Higher Education, 2 (2019).

${ }^{38}$ INQAAHE was established in 1991. It states its mission as follows "The central purpose and role of INQAAHE is to promote and advance excellence in higher education through the support of an active international community of quality assurance agencies. In order to achieve the goal, the Network focuses on the development of the theory and practice of quality assurance, the exchange and understanding of the policies and actions of its members, and the promotion of quality assurance for the benefit of higher education, institution, students and society at large." https://www.inqaahe.org/

${ }^{39}$ APQN was founded in 2003 for the purpose of "enhancing the quality of higher education in the AsiaPacific region" and "dissolving boundaries for a quality region". It is located in Shanghai-China. https:// www.apqn.org/

40 The Constitution of the Asia- Pacific, Quality Network, March 2014. The APQN also aims "to permit better informed international recognition of qualifications throughout the region.”.

Id at II.4.6.

${ }^{41}$ Id at 4.8 .
} 
The National Council for Accreditation of Teacher Education [NCATE] ${ }^{42}$ and the Center for Quality Assurance in International Education ${ }^{43}$ collaborated in defining quality education in accordance with the accreditation standards developed by NCATE. They are six; based on candidates' knowledge, skills, professional dispositions, assessment system and limit evaluation; field experiences and clinical practice, diversity, faculty qualifications, performance and development, and the unit governance and resources.

The United Nations Educational, Scientific and Cultural organization [UNESCO] issued in 2008 an advisory statement titled "Toward Effective Practice: Discouraging Degree Mills in Higher Education," in collaboration with CHEA ${ }^{44}$ and in 2016, both issued an "Advisory statement for Effective International Practice: Combatting Corruption and Enhancing Integrity: A Contemporary Challenge for the Quality and Credibility of Higher Education". ${ }^{45}$ In 2019, the two organizations developed a set of questions that are essential for quality assurance and accreditation in combating academic corruption and enhancing integrity. These questions included, "whether your organization has a working definition of "academic corruption", whether it has a public commitment to reducing academic corruption, whether it is accountable to the public in terms of transparency and integrity of its own activities, whether it is prepared to challenge higher education providers about corrupt practices, whether it is proactive in monitoring suspicions of misconduct and academic corruption in its activities, whether it arranges site visits with short notice to higher education institutions, whether it provides support to higher education providers for developing educational and research quality standards, whether it interacts with other higher education stakeholders to combat academic corruption, whether it is involved in networking activities with relevant bodies at local level, such as the media, to share practices, whether it is active in advocating legislation with the following objectives: countering degree and accreditation mills and contract cheating companies, regulating better leadership and governance of higher education providers, and providing protection for whistleblowers, whether it conducts research to inform and enhance policy and

\footnotetext{
${ }^{42}$ NCATE does not accredit teacher education schools outside the U.S. However, in response to international interests in its standards and guidelines, NCATE makes them available for international universities in conducting their academic reviews. http://www.ncate.org/

${ }^{43}$ The Center is a non-profit higher education association located in D.C. in the U.S., with offices in Abu Dhabi, United Arab Emirates and Hanoi, Vietnam. https://uia.org/

${ }^{44}$ The Advisory statement lists a number of indications of degree mills including "lack of legal authority to operate as higher education institutions or award degrees, requiring little of any attendance, either on site or online, requiring little if any coursework or few if any assignments to obtain a credential, not providing information about location of incorporation, ownership or governance, providing little or no contact information other than telephone or email addresses, publishing false or exaggerated claims of external quality review (accreditation or quality assurance), issuing degrees that are not accepted for licensing or entry into graduate or professional programs in the degree mill's home country, listing academic staff whose degrees were issued by degree mills or are unable to provide verifiable lists of academic staff and their qualifications, plagiarizing material from legitimate institutions for inclusion on degree mill websites and featuring websites with internet domain registration that is obscured by a privacy service rather than being publicly accessible". https://www.chea.org/

${ }^{45}$ This Advisory statement covers combatting corruption in seven areas including the regulation of higher education systems, the teaching role of higher education institutions, student admissions and recruitment, student assessment, credentials and qualifications, research theses and publications and combatting corruption through public awareness, https://unesdoc.unesco.org/ark:/48223/pf0000249460/PDF/249460eng.pdf. multi
} 
practices that address corruption in education and research, and whether it has formed an informal link with quality assurance bodies in the education sector." 46

The Association to Advance Collegiate Schools of Business (AACSB) ${ }^{47}$ sets principles for accreditation that are based on core values especially encouraging and supporting "ethical behavior" by students, faculty, administrators and professional staff, in addition to maintaining "collegiate environment" 48 and a commitment to "corporate social responsibility". 49

The Foundation for International Business Administration Accreditation [FIBAA] ${ }^{50}$ accredits academic institutions in accordance with the Standards of the German Accreditation Council and the standards embodied in European Standards and Guidelines (ESG). The Standards and Guidelines for Quality Assurance in the European Higher Education [ESG] of 2015 emphasize academic Integrity. ESG was initially adopted in 2005 as a result of a cooperative effort made by the European Association for Quality Assurance in Higher Education (ENQA), the European Students Union (ESU), the European Association of Institutions in Higher Education (EURASHE) and the European University Association (EUA) ${ }^{51}$ The 2015 version is a product of revisions that were then adopted by the Ministers responsible for higher education in European Higher Education. ${ }^{52}$ Quality assurance policies, according to the ESG standards, should support "academic integrity and freedom and its vigilant against academic fraud." 53 Furthermore, institutions should "apply fair and transparent processes for the recruitment and development of the staff." 54 Institutions should also "publish information about their activities, including programs,

46 CHEA and the UNESCO, Combatting Academic Corruption and Enhancing Integrity: Inventory of Key Questions for Quality Assurance and Accreditation Organizations (August 2019).

47 AACSB was founded in 1916 and adopted its first standards for degree programs in business administration in 1919. In 1980 AACSB established additional standards in accounting: Its standards has been revised constantly in 1991, 2003 and 2013. AACSB is recognized by the Council for Higher Education Accreditation (CHEA). AACSB accreditation requires evidence of progress in quality in three main areas, engagement, innovation and impact, https://www.aacsb.edu/accreditation/standards\#gsc.tab $=0$

48 AACSB defines "collegiate environments" as environments that are "characterized by scholarships, scholarly approaches to business and management, and a focus of advanced learning." https://www. aacsb.edu/-/media/aacsb/docs/accreditation/business/standards-and-tables/2018-business-standards. ashx?la=en\&hash=B9AF18F3FA0DF19B352B605CBCE17959E32445D9

49 As stated by AACSB International Criteria and Standards for Business Accreditation "The school must demonstrate a commitment to address, engage, and respond to current and emerging corporate social responsibility issues (e.g., diversity, sustainable development, environmental sustainability, and globalization of economic activity across cultures) through its policies, procedures, curricula, research and/or outreach activities." (Part 1: Core Values and guiding Principles.) https://www.aacsb.edu/-/media/ aacsb/docs/accreditation/business/standards-and-tables/2018-business-standards.ashx ?la=en\&hash= B9AF18F3FA0DF19B352B605CBCE17959E32445D9

50 FIBAA was founded in 2002 to accredit schools of business. Now it accredits other schools as well, not only in Germany but also internationally. As stated in its 2018 FIBAA Annual Report " As an Accreditation agency, we see the promotion of quality, transparency and comparability in higher education and science as our mission" The Report acknowledgments the new legal basis for accreditation of 2018 that emphasizes gender equality and equal opportunities for the disadvantaged. https:/www.fibaa.org/en/welcome-page.html 51 https://eua.eu/

52 See, Foreword, Standards and Guidelines for Quality Assurance in the European Higher Education Area (ESG), (2015), https://enqa.eu/index.php/home/esg/.

53 ESG 1.1 Policy for Quality Assurance, Guidelines. The ESG outlines four principles for quality assurance, "Higher education institutions have primary responsibility for the quality of their provision and its assurance", "Quality assurance responds to the diversity of higher education systems, institutions, programs and students", "Quality assurance supports the development of a quality culture", and "Quality assurance takes into account the needs and expectations of students, all other stakeholders and society." Id. ${ }^{54}$ ESG, 1.5 Teaching Staff. 
which is clear, accurate, objective, up-to-date and readily accessible". ${ }^{5}$ They should also regularly monitor, review and revise their programs. These reviews should also be published. ${ }^{56}$ Institutions should have access to processes of complaints and appeals if they are not satisfied with the conduct of the external quality assurance processes. ${ }^{57}$ Agencies conducting external quality assurance should ensure "the independence of the experts" 58 who are carrying out the interview, "by implementing a mechanism of no-conflict-ofinterest". ${ }^{59}$ Their reports should also be published. ${ }^{60}$ The agencies should be independent. ${ }^{61}$ "Independence is important to ensure that any procedures and decisions are solely based on expertise". ${ }^{62}$ They should have in place "processes for internal quality assurance related to defining assurance and enhancing the quality and integrity of their activities". ${ }^{63}$

The International Association of Law Schools ${ }^{64}$ adopted three main documents that emphasize academic integrity. The Singapore Declaration on Global Standards and Outcomes of a Legal Education establishes "transparency" as a main principle in the regulation of legal education, selection of students and their evaluation, and recruitment of faculty. ${ }^{65}$ Again, "transparency" was recognized in the Madrid Protocol on the Principles of Evaluation of Legal Education; as one of the standards of any evaluation process. ${ }^{66}$ The Judicial Standards of a Legal Education ${ }^{67}$ provides that "the law and legal processes should be fair and transparent" and a legal education should "teach, model and shape a student's

\footnotetext{
55 ESG, 1.8 Public Information.

56 ESG, 1.9 On-Going Monitoring and Periodic Review of Programs.

57 ESG, 2.7 Complaints and Appeals.

58 ESG, 2.4 Peer-Review Experts.

59 ESG, 2.4 Peer-Review Experts.

60 ESG, 2.6 Reporting.

61 ESG, 3.3 Independence.

62 Id.
}

63 ESG, 3.6 Internal Quality Assurance and Professional Conduct. The Guidelines to their standards states that agencies should have policies that ensure that "all persons involved in its activities are competent and act professionally and ethically" and guard "against intolerance of any kind of discrimination" Id.

64 Dr. Mohamed Abdulaziz Al-Khulaifi, Dean of College of Law at Qatar University was appointed as a member of the board of governance of IALS starting January 2021. The International Association of Law Schools [IALS] was incorporated under the laws of the District of Columbia in the U.S. to "Foster mutual understanding of and respect for the world's varied and changing legal systems and cultures as a contribution to justice and a peaceful world, enhance and strengthen the role of law in the development of societies through legal education, serve as an open and independent forum for discussion of diverse ideas about legal education, contribute to the development and improvement of law schools and conditions of legal education throughout the world, contribute to better preparation of lawyers as they increasingly engage in transnational or global legal practice (and) share experience and practices regarding legal education" Article 2 of the International Association of Law Schools By laws, https://www.ialsnet.org/charter-bylaws/.

65 Adopted by the International Association of Law Schools at the inaugural Global Law Deans' Forum, held at the National University of Singapore Faculty of Law, 26 September 2013, The Singapore Declaration also emphasized "values" as one of the main outcomes of a legal education, stating that "a law graduate should know and understand the need to act in accordance with i. The professional ethics of the jurisdiction, and ii. The fundamental principles of justice and the rule of law." https://www.ialsnet.org/wp-content/uploads/ 2015/10/Singapore-Declaration-2013.pdf

66 Adopted by the International Association of Law Schools at the $2^{\text {nd }}$ Global Law Deans' Forum, held at IE University, IE School of Law, Madrid, Spain, 27 October 2015. https://www.ialsnet.org/wp-content/ uploads/2016/05/Madrid-Protocol-Final.pdf

67 Adopted by the International Association of Law Schools Judicial Council in October 28,2017. https:// www.ialsnet.org/wp-content/uploads/2017/12/Judicial-Standards-of-a-Legal-Education.pdf 
course of the moral and ethical responsibilities of someone trained in the law". ${ }^{68}$ Based upon these principles the International Association of Law Schools established a new program titled "Evaluation, Assistance and Certification". Five standards are evaluated; regulations, students, faculty, curriculum and infrastructure, and three outcomes of a legal education, knowledge, skills and values. The self-assessment report designed by the International Association of Law Schools asks a law school to describe how does the school instruct its students in "Social responsibly and ethical standards of the profession".

The Singapore Statement on Research Integrity ${ }^{69}$ calls for adherence to four principles including "honesty in all aspects of research, accountability in the conduct of research, professional courtesy and fairness in working with others and good stewardship of research on behalf of others." 70

According to the International Centre for Academic Integrity, ${ }^{71}$ academic integrity is defined as "a commitment even in the face of adversity, to six fundamental values: honesty, trust, fairness, respect, responsibility and courage."

In Africa, the Dar es Salaam Declaration on Academic Freedom and Social Responsibilities of Academics of 1990 provided for several principles that ensure academic integrity including its stipulation that "Access to education shall be equal and equitable", 72 and that "All members of the academic community have the right to fulfill their functions of teaching, researching, writing, learning, exchanging and disseminating information and providing services without fear of interference or repression from the State or any other public authority". ${ }^{73}$ The Declaration further provides that "institutions of higher education shall be independent of the State or any other public authority in conducting their affairs and setting up their academic, teaching, research and other related programs. The State is under an obligation not to interfere with the autonomy of institutions of higher education". ${ }^{74}$ The Declaration provides that "All members of the academic community have a responsibility to fulfill their functions and academic roles with competence, integrity and to the best of their abilities. They should perform their academic functions in accordance with ethical and highest scientific standards". 75

\footnotetext{
68 The Judicial Standards further state that legal education should provide a law student with the understanding that "decisions made in accordance with the law should embody the values of consistency with established law and objective legal principles, due process in transparent procedures as to the administration of law, natural determinations supported by the weight of acceptable evidence, equality for all before the law; and proportionality as to the result." https:/www.ialsnet.org/wp-content/uploads/2017/12/JudicialStandards-of-a-Legal-Education.pdf

69 The Singapore Statement on Research Integrity was drafted in 2010 at the second world conference on Research Integrity. In its preamble, the statement recognizes that "The value and benefits of research are vitally dependent on the integrity of research. http://www.singaporestatement.org.

70 The statement also emphasizes a number of responsibilities including publication acknowledgment, ie "researchers should acknowledge in publications the names and roles of those who made significant contributions to the research..."; and conflict of interest ie "researchers should disclose financial and other conflict of interest that could compromise the trustworthiness of their work in research proposals, publications and public communications as well as in all review of activities." Id.

71 The Centre was established in 1992 to combat academic dishonesty in higher education. It organizes an annual conference. https://www.academicintegrity.org/

72 Chapter one (2) http://hrlibrary.umn.edu/africa/DARDOK.htm

73 Chapter one, Rights and Freedoms (14) http://hrlibrary.umn.edu/africa/DARDOK.htm

74 Part III Autonomy of Institutions of Higher Education, (para 38). http://hrlibrary.umn.edu/africa/ DARDOK.htm

75 Chapter two - Responsibility of Academics, Para 46. Paragraph 49 further states that "No member of the academic community shall participate in or be a party to any endeavor which may work to the detriment
} 
In the United States, the Council for Higher Education Accreditation ${ }^{76}$ promotes academic quality through accreditation and adopts a policy that emphasizes high accreditation standards that must be followed by accrediting institutions including demonstration of public accountability for performance and transparency.

The Arab Organization for Quality Assurance in Education (AROQA) ${ }^{77}$ provides training on quality assurance and accreditation of universities in the Arab region. Arab guide for quality assurance and accreditation of universities of 2015 defines university ethics to include "policies that ensure academic integrity that must be published and should include accurate and well defined information about the university vision, mission and objectives, programs, curricula, academic degrees, tuition, financial status, admission conditions, graduation requirements, ethical and professional code of conduct, strict system of sanctions and rewards, transparency in financial administrative transaction, ethical limitations in use of modern technology, equal opportunities and justice in hiring and promotions, community service, right of complaint and appeal, academic freedom and students' feedback of faculty performance". ${ }^{78}$

While academic integrity is an important indicator for granting accreditation, accrediting agencies do not always ask the question whether the academic institution has an explicit policy on academic integrity. Inquiries must be made into whether such policy provides for a clear definition of violations that constitute breach of academic integrity, whether there are specific procedures for hearings and resolutions of such violations, whether there are strict sanctions for these violations and whether there is an appeal process to ensure fai rness and justice in any particular case.

In their answer to our questionnaire, for instance the British Accreditation Council (BAC) referred to key indicators to identify academic corruption including whether "the institution takes appropriate steps to identify and discourage cheating including plagiarism and other misdemeanors and to penalize offenders" and whether "the institution verifies that the student who registers in the programme is the same student who participates in the program and completes and receives the credit." However, BAC the does not ask the academic institution to provide a specific and explicit policy on academic integrity.

Similarly, The Association to Advance Collegiate School of Business (AACSB) made it clear, in their response to our questionnaire, that its "standards are not prescriptive and therefore do not specify specific definitions for academic integrity", and that "the school is expected to have appropriate policies and procedures that attest to a strong emphasis on ethical behavior, as well as a mechanism for identifying and remediating behavior by those associated with the conduct of the business school." However, the AACSB does not require

\footnotetext{
Footnote 75 (continued)

of the people or the academic community or compromise scientific, ethical and professional principles and standards". http://hrlibrary.umn.edu/africa/DARDOK.htm

76 The Council for Higher Education Accreditation (CHEA) was founded in 1996. As stated in its mission statement "CHEA will serve students and their families, colleges and universities, sponsoring bodies, governments and employers by promoting academic quality through formal recognition of higher education accreditation bodies and will coordinate and work to advance self-regulation through accreditation." https:// www.chea.org/

77 AROQA is an international non-profit independent association that was established in Belgium in 2007 with the objective of developing standards, supporting provision of self-evaluation, providing quality assurance and accreditation services, promoting cooperation and joint projects in education and research, developing quality in educational institutions and providing training and capacity, building programs. http:// aroqa.org/en

78 Guide for Quality Assurance and Accreditation for Universities, Education by Correspondence and E-learning, The Union for Arab Universities, 2015.
} 
an academic institution to submit a comprehensive and independent policy on academic Integrity.

It is not entirely clear how does the process of accreditation and rankings contribute to the enhancement of academic integrity of an academic institution. At least, based upon my experience with Qatar University, especially at the College of Law where I served for many years as the chair of the Quality Assurance and International Academic Accreditation Committee, I can attest to the significant impact of this process in driving the university to fully and effectively comply with the international standards in quality assurance and academic accreditation.

So how do universities adopt policies, principles, guidelines, procedures, rules and regulations that are designed to fulfill the quality assurance standards regarding academic integrity that are required by accreditation and ranking institutions? I will try to answer this question by examining Qatar University rules and practices as a model for combating academic corruption and enhancing academic integrity. I will ask, in particular, to what extent do the adopted policies adhere to the main principles of human rights especially nondiscrimination and protection of the vulnerable? How do these Univeristy guidelines implement the basic tenets of corporate social responsibility? How are the procedures, rules and regulations designed to combat corruption? and how are they being drafted to meet environmental standards? I will also suggest the adoption of more specific and special policies on anti-radicalization and extremism measures, protection of underage students and social media usage among students.

\section{Second: Policies, Guidelines, Procedures, Rules and Regulations Promoting Academic Integrity in Educational Institutions: The Model of Qatar University}

History and Structure: Qatar University was established in 1973. It is a state university located in Doha, Qatar. The university hosts ten colleges - Arts and Sciences, Business and Economics, Education, Engineering, Law, Sharia and Islamic Studies, Pharmacy, College of Health Science, College of Medicine, and the latest College of Dental Medicine.

Ranking and Accreditation: Qatar University maintains its world ranking of the Times Higher Education (THE) ${ }^{79}$ among the top $500^{80}$ based upon the following five indicators; Teaching (the learning environment); Research (volume, income and reputation); Citations (research influence); International outlook (staff, students and research); and Industry Income (knowledge transfer). In the QS World University Ranking, ${ }^{81}$ QU moved from 332 in 2019 to 276 in the 2020 ranking and to 245 in the 2021 ranking $^{82}$ based on these indicators; academic reputation,

\footnotetext{
79 https://www.timeshighereducation.com/world-university-rankings/world-university-rankings2020methodology

${ }^{80}$ Dr. Hassan Rashid Al-Derham is the current president of the University. The performance indicators are grouped into five areas: Teaching 30\% (the learning environment); Research 30\% (volume, income and reputation); Citations 30\%(research influence); International outlook 7.5\% (staff, students and research); and Industry Income 2.5\% (knowledge transfer). https://www.timeshighereducation.com/world-university-rankings/world-university-rankings2020-methodology

81 https://www.topuniversities.com/asia-rankings/methodology

82 The 11 indicators used to compile the QS Asia University Ranking are: Academic Reputation (30\%), Employer Reputation (20\%), Faculty/ Student ratio (10\%), International Research Network (10\%), Citation per Paper (10\%) and papers per faculty (5\%), Staff with a PhD (5\%), Proportion of International Faculty
} 
employer reputation, faculty/ student ratio, international research network, citation per paper and papers per faculty, staff with a $\mathrm{PhD}$, proportion of international faculty and proportion of international students, proportion of inbound exchange students and proportion of outbound exchange students.

Many of the colleges of Qatar University are accredited as institutions or regarding the programs that they are offering. For instance, The Bachelor of Law program at the College of Law at Qatar University was accredited by the High Council of Evaluation of Research and Higher Education (HCERES) ${ }^{83}$ in France for five years. ${ }^{84}$ The College of Law also obtained an institutional accreditation for four years from the British Accreditation Council (BAC) $)^{85}$ in the UK. ${ }^{86}$ Other colleges at Qatar University are also accredited. The college of Business and Economics is accredited by the Association to Advance Collegiate Schools of Business (AACSB) ${ }^{87}$ the College of Education is accredited by the International Recognition in Teacher Education (IRTE), ${ }^{88}$ the Association for Childhood Education International (ACEI), ${ }^{89}$ the Council for Exceptional Children (CEC), ${ }^{90}$ and the National Association for the Education of Young Children (NAEYC). ${ }^{91}$ The college of Arts and Science is accredited by several accrediting agencies. Its Environmental Sciences Program (BSc. And MSc.) is accredited by both the Committee of Heads of Environmental Sciences $(\mathrm{CHES})^{92}$ and the Institute on Environmental Sciences (IES) ${ }^{93}$ in U.K. Its Mass Communication program is accredited by the Accrediting Council on Education in Journalism and Mass Communication (ACEJMC), ${ }^{94}$ Its Biomedical Sciences Program is accredited by the National Accrediting Agency for Clinical Laboratory Sciences (NAACLS), ${ }^{95}$ its Statistics Program is accredited by the Royal Statistical Society (RSS), ${ }^{96}$ its chemistry Program is accredited by the Canadian Society for Chemistry (CSC) ${ }^{97}$ and its Human Nutrition, BS is accredited by the Accreditation Council for Education in Nutrition and Dietetics. The College of Pharmacy is accredited by the Canadian

Footnote 82 (continued)

(2.5\%) and proportion of international students (2.5\%), Proportion of inbound exchange students $(2.5 \%)$ and proportion of outbound exchange students (2.5\%). https://www.topuniversities.com/asia-rankings/ methodology

83 https://www.hceres.fr/en

84 The accreditation was granted in April 2016.

85 https://www.the-bac.org/

86 The accreditation was granted in July 2016. Other law schools in the Arab region were granted accreditation. Abu Dhabi University College of Law was accredited by WASC in the U.S., Al Ain University of Science and Technology Bachelor of law was accredited by the HCERES in France, King Saudi University Bachelor of law was also accredited by the HCERES in France, the College of law at Sultan Qabous University was accredited by the FIBAA in Germany, Beirut Arab University law program was also accredited by FIBAA in Germany, Kuwait International Law School was certified by QAA in UK and Baghdad University Faculty of Law was accredited by IAO in the U.S.

87 https://www.aacsb.edu/accreditation

88 https://www.kfu.edu.sa/en/Deans/QA/Documents/Intl_Teacher_Ed_Manual.pdf

89 https://acei.org/

90 https://www.cec.sped.org/

91 https://www.naeyc.org/

92 http://ches.info/accreditation.html

93 https://www.the-ies.org/

94 http://www.acejmc.org/

95 https://www.naacls.org/about.aspx

96 https://rss.org.uk/

97 https://www.cheminst.ca/about/about-csc/ 
Council for Accreditation of Pharmacy Program (CCAPP).$^{98}$ The College of Engineering is accredited by the Engineering Accreditation Commission (ABET),${ }^{99}$ and the Computing Accreditation Commission of ABET.

Seeking international accreditation by these academic institutions is explained by an absence of any credible and effective regional accreditation agency, as we previously discussed. It is also motivated by a desire to achieve higher ranking and compete with similar academic institutions around the world.

A Vision and a Strategy: As stated in Qatar Vision 2030 "Qatar aims to build a modernclass educational system that provides students with a first-rate education, comparable to that offered anywhere in the world." 100 Qatar University Strategy 2018-2022 is based on a commitment to the value of "integrity" which it defines to include commitment to "the highest ethical standards of honesty, fairness, transparency, responsibility and accountability". The Strategy outlines six core values that will enable the University to achieve its goals, including excellence,${ }^{101}$ academic freedom, ${ }^{102}$ innovation, ${ }^{103}$ integrity, ${ }^{104}$ diversity ${ }^{105}$ and social responsibility. ${ }^{106}$

Corporate Social Responsibility Standards: Qatar University joined the United Nations Global Compact on Corporate Social Responsibility, which outlines ten principles ${ }^{107}$ that

$98 \mathrm{http} / / / \mathrm{ccapp}-$ accredit.ca/
$99 \mathrm{https} / /$ www.abet.org/accreditation/

${ }^{100}$ Qatar Vision 2030 further states that "The system will provide citizens with excellent training and opportunities to develop to their full potential, preparing them for success in a changing world with increasingly complex technical requirements. The system will also encourage analytical and critical thinking, as well as creativity and innovation. It will promote social cohesion and respect for Qatari society's values and heritage, and will advocate for constructive interaction with other nations." https://www.gco.gov.qa/wp-content/ uploads/2016/09/GCO-QNV-English.pdf

${ }^{101}$ As stated in the strategy "Qatar University is committed to excellence in everything it does and to the highest standards of quality and professionalism." http://www.qu.edu.qa/file_source/qu/about/documents/ Qatar\%20University\%20Strategy\%202018-2022\%20Booklet\%20-\%20EN.pdf

${ }^{102}$ As stated in the strategy "Qatar University is committed to an environment that supports responsible freedom of inquiry, expression and the search for truth." http://www.qu.edu.qa/file_source/qu/about/documents/ Qatar\%20University\%20Strategy\%202018-2022\%20Booklet\%20-\%20EN.pdf

103 As stated in the strategy "Qatar University fosters innovation by encouraging its students, faculty and staff to explore novel ideas in an environment of free and open inquiry, to pursue the discovery and application of knowledge and to develop innovative solutions" http://www.qu.edu.qa/file_source/qu/about/documents/Qatar\% 20University\%20Strategy\%202018-2022\%20Booklet\%20-\%20EN.pdf

104 As stated in the strategy "Qatar University is committed to integrity and to the highest ethical standards of honesty, fairness, transparency, responsibility, and accountability" http://www.qu.edu.qa/file_source/qu/ about/documents/Qatar\%20University\%20Strategy\%202018-2022\%20Booklet\%20-\%20EN.pdf

105 As stated in the strategy "Qatar University embraces diversity that respects religious and cultural tenets, and considers a diverse faculty and student body a source of strength that enriches its educational and work environment.” http://www.qu.edu.qa/file_source/qu/about/documents/Qatar\%20University\%20Strategy\%202018-2022\% 20Booklet\%20-\%20EN.pdf

106 As stated in the strategy "Qatar University promotes positive and proactive engagement with the community, grounded in a sense of its aspirations and needs." http://www.qu.edu.qa/file_source/qu/about/ documents/Qatar\%20University\%20Strategy\%202018-2022\%20Booklet\%20-\%20EN.pdf

107 These principles are: 1: Businesses should support and respect the protection of internationally proclaimed human rights; 2: make sure that they are not complicit in human rights abuses, $\underline{3}$ : Businesses should uphold the freedom of association and the effective recognition of the right to collective bargaining; 4: the elimination of all forms of forced and compulsory labour; 5 : the effective abolition of child labour; 6: the elimination of discrimination in respect of employment and occupation; 7: Businesses should support a precautionary approach to environmental challenges; 8: undertake initiatives to promote greater environmental responsibility; 9:encourage the development and diffusion of environmentally friendly technologies and 10 : Businesses should work against corruption in all its forms, including extortion and bribery. http://www.qu.edu.qa/file_ source/qu/about/documents/Qatar\%20University\%20Strategy\%202018-2022\%20Booklet\%20-\%20EN.pdf 
are based on four main concepts; respect for human rights, observance of labour rights, compliance with environmental standards and adopting anti-corruption measures. The question becomes how does an academic institution such as Qatar University implement these principles ${ }^{108}$ The University established a center for voluntarism that is designed to recruit students to volunteer inside and outside the university.

Qatar University is also a member of the United Nations Academic Impact (UNAI), ${ }^{109}$ which also provides ten principles ${ }^{110}$ that are designed to advance a role of universities in achieving equal opportunity and global citizenship. ${ }^{111}$

A Human Rights Policy?: While Qatar University does not adopt a specific policy that explicitly provides for respect of human rights, ${ }^{112}$ it covers the main aspects of a human rights platform especially non-discrimination, freedom of expression, inclusion and diversity.

Freedom of expression is to be balanced with an anti-radicalization and extremism policy. While Qatar University does not have an independent explicit policy that carries this title, it takes different measures to avoid radicalization or extremism including monitoring students' literature and posters, ${ }^{113}$ reviewing external speakers and guests, ${ }^{114}$ adopting a

108 See, "A Practical Guide for the United Nations Global Compact for Higher Education Institutions 2012.".

109 https://academicimpact.un.org/content/about-unai

110 The ten principles are: 1: A commitment to the principles inherent in the United Nations Charter as values that education seeks to promote and help fulfill; 2: A commitment to human rights, among them freedom of inquiry, opinion, and speech; 3: A commitment to educational opportunity for all people regardless of gender, race, religion or ethnicity; 4: A commitment to the opportunity for every interested individual to acquire the skills and knowledge necessary for the pursuit of higher education; 5: A commitment to building capacity in higher education systems across the world; 6: A commitment to encouraging global citizenship through education; 7: commitment to advancing peace and conflict resolution through education; 8: A commitment to addressing issues of poverty through education; 9: A commitment to promoting sustainability through education and 10: A commitment to promoting inter-cultural dialogue and understanding, and the "unlearning" of intolerance, through education. https://academicimpact.un.org/content/principles

111 See generally, Harkavy, I. (2006). The role of universities in advancing citizenship and social justice in the twenty-first century. Education, citizenship and social justice, 1(1), 5-37. SAGE Publications, concluding that "when colleges and universities give very high priority to actively solving strategic, real world, problems in their local community, a much greater likelihood exists that they will significantly advance citizenship, social justice and public good" Id at 33.

112 See generally, Mattar M. Y. (2013). Article 43 of the Arab Charter on Human Rights: Reconciling National, Regional, and International Standards. Harvard Human Rights Journal, Volume 26, p. 91-147. See for instance, the University of Guelph "Human Rights Policy" https:/www.uoguelph.ca/diversity-human-rights/sites/default/files/Human\%20Rights\%20Policy_0. pdf See also Simon Fraser University "Human Rights Policy" https://www.sfu.ca/policies/gazette/general/gp18.html\#: : text=Simon $\% 20$ Fraser\%20University \%20promotes $\% 20$ teaching,and $\% 20 \mathrm{critical} \% 20$ discussion $\% 20$ of $\% 20 \mathrm{ideas} . \&$ text= Discrimination \% 20undermines\%20these \%20objectives\%2C\%20violates,remedial\%20action\%20by $\% 20$ the $\%$ 20University. The focus of a human rights policy is prevention of discrimination and harassment. See E.g. Ryerson University https://www.ryerson.ca/policies/policy-list/dhppolicy/\#: :text=Ryerson\%20University's\%20Discrimination\%20and\% 20Harassment\%20Prevention\%20Policy\%20and\%20Procedures\%20are,and\%20facilitative\%20for\%20all\%20parties. The American Bar Association in standard 205 “A" "B" "D" on "Non-discrimination and Equality of Opportunity" https://www. americanbar.org/content/dam/aba/administrative/legal_education_and_admissions_to_the_bar/standards/2019-2020/2019-2020aba-standards-chapter2.pdf

113 Code of Conduct "Unauthorized posting of signs, notices, flyers, banners, and announcements." http:// www.qu.edu.qa/students/code-of-conduct

114 QU External Relations Handbook: http://www.qu.edu.qa/static_file/qu/offices\%20and\%20departments/ Communications\%20\&\%20Public\%20Affairs\%20Department/documents/Event\%20planning\%20instructios/ 10-QUER_Policies_22Jan2009.pdf 
policy of tolerance and acceptance of others, ${ }^{115}$ raising awareness about the causes and consequences of extremism, ${ }^{116}$ training on anti-terrorism policies ${ }^{117}$ and collaborating with international organizations in the fight against terrorism. ${ }^{118}$ Perhaps a more comprehensive policy would be more appropriate.

Non-discrimination in admission: Qatar University adopts a policy of nondiscrimination on the basis of race, gender or religion. International students are admitted on a competitive basis according to individual merit, as determined by the university. Qatar University also ensures that all its facilities are accessible to special-needs students. ${ }^{119}$ The university offers excellent candidates scholarships exempting students from tuition and books fees. Qatar University also supports Fulbright's scholars.

Qatar University also adopts a policy that takes into consideration the rights of persons with disabilities or special needs, "To provide programs and services that ensure fair and appropriate access to programs, services, facilities, and activities for students with special needs, within the proper environment", based upon the principle of inclusion ${ }^{120}$ and to achieve the principle of equal opportunities for all. ${ }^{121}$

When students under the age of 18 are admitted, the University should take special measures to protect them including identifying appropriate accommodation arrangements, providing them with children's social care, and protecting them against child abuse or any other form of violence, neglect, maltreatment or exploitation. Here also, it is advisable that Qatar University adopts a specific policy covering under age students.

To provide legal aid to the vulnerable, especially migrant workers, a law clinic was established at the College of Law at Qatar University, which offers pro-bono services in collaboration with a network of lawyers who volunteer their work and assist the different sectors of the Qatari society. ${ }^{122}$ The objective of the law clinic is providing legal aid to the vulnerable groups in the Qatari society through legal representation. ${ }^{123}$

115 Code of Conduct "Such freedom, in turn, depends on the good will and responsible behavior of all members of the community, who must treat each other with tolerance and respect." http://www.qu.edu.qa/ students/code-of-conduct

$116 \mathrm{https} / /$ www.qu.edu.qa/static_file/qu/research/SESRI/documents/SESRI\%20in\%20media/2019/gulf\% 20times\%209-8.pdf

117 http://its.qu.edu.qa/newsroom/Qatar-University/Qatar-University-to-Develop-Counter\%E2\%80\%93TerroristFinancing-Training

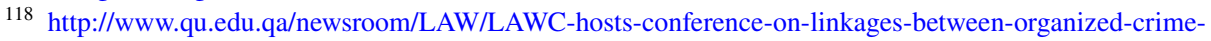
and-terrorism

119 http://www.qu.edu.qa/education/academic-programs/graduate/arts-in-curriculum/How-to-Apply

120 As stated in the policy: "Inclusion is to integrate students with special needs effectively in regular education setting and the society. This happens by building an environment of awareness and acceptance, such as providing appropriate support services and equipment. Qatari Law declares that these students must be educated in the "least restrictive environment appropriate" to meet their "unique needs."' http://www. qu.edu.qa/artssciences/deans-office/assistant-dean-students/special-needs

121 The policy aims at achieving the following goals: "Offer the best services for students respective to their own needs, Involve student in different activities, Provide and help establish a supportive and accessible university environment, Coordinate with other specialists to achieve these goals." http://www.qu.edu.qa/ artssciences/deans-office/assistant-dean-students/special-needs

122 https://www.qu.edu.qa/law/departments/legal-skills/law-clinic

123 I was previliged to serve as the director of the law clinic since its inception. "The law clinic is designed to perform the following activities; carrying out legal projects in legislative drafting and legal reform; raising awareness about legal rights through a street law program; reporting on human rights violations through fact finding missions and monitoring mechanisms; incorporating experiential legal studies in educational curricula in the different branches of law; establishing partnerships and engaging national; regional and international stakeholders and releasing a series of publications to support the work of the law clinic and contribute to experiential legal education". https://www.qu.edu.qa/law/departments/legal-skills/law-clinic 
A center for community service and continuing education was established "aimed at promoting volunteerism, leadership and civic responsibility." ${ }^{124}$ In fact, assessment of performance of faculty members is based on four main criteria namely, teaching, research, self-development and community service. ${ }^{125}$

Labor Rights: Qatar University policy also observes labour rights in employment contracts and hiring policies, strives to become a "model employer", ${ }^{126}$ and maintains a "friendly work environment" 127 and "a workplace that reflects the diversity of the broader population." 128

Verification in Recruitment: In accordance with the "Academic Recruitment Guide" of Qatar University, "it is the university's policy to verify academic credentials claimed by a prospective faculty and staff members. Should the verification not bear out the claim, any offer of employment to the individuals will be withdrawn, or, when necessary, the individual's appointment at the institution will be terminated."129

Environmental Policy: It is the policy of the procurement and contracts department to acquire goods and services "in accordance with the plans and objectives set by the higher management of the Qatar University, where modern methods of procurement are applied in order to obtain the best competitive prices in terms of the quality of products and services and build good relations with suppliers in line with the interests of the University of Qatar." ${ }^{130}$ It is advisable that Qatar University explicitly provides for an environmental policy to acknowledge its commitment to the protection of the environment, especially

\footnotetext{
124 http://www.qu.edu.qa/cce/about

125 Faculty Performance Review and Development System Guidelines \& Policies https://www.qu.edu.qa/static file/qu/offices\%20and\%20departments/VPAA/documents/ACADEMIC_029_QU_Faculty_Performance_Review_ and_Development_System_EMC_Approved_V01_Sep17_2014.pdf

126 As stated in Qatar University human resources strategy and work plan "Becoming a model employer in the region demands a higher standard of employment practices. We must strive for transparency, fairness, and accountability. We must build a working culture that engages and inspires all employees for the betterment of the education provided to the students of Qatar University." https://www.qu.edu.qa/static_file/qu/ offices\%20and\%20departments/Human\%20resources/documents/Human_Resources_Strategy_and_Work_ Plan.pdf

127 As stated in Qatar University human resources strategy and work plan "Retention of qualified employees requires up-to-date workforce policies and programs that clearly demonstrate our commitment to the quality of our work environment, promote work-life balance and are flexible and family friendly." https://www.qu. edu.qa/static_file/qu/offices\%20and\%20departments/Human\%20resources/documents/Human_Resources_ Strategy_and_Work_Plan.pdf

128 The expected outcomes include "a workplace that reflects the diversity of the broader population and welcomes cultural differences as evidenced by annual review of our employee demographics" https://www.qu. edu.qa/static_file/qu/offices\%20and\%20departments/Human\%20resources/documents/Human_Resources_ Strategy_and_Work_Plan.pdf

129 Furthermore, the Guide provides that "An applicant who provides misleading, erroneous, or deceptive information on a profile, resume, or in an interview will be immediately eliminated from further consideration for employment" https:/www.qu.edu.qa/static_file/qu/offices\%20and\%20departments/VPAA/documents/ vpaa_academic_recruitment_guide_vpcao_fall_2010.pdf
}

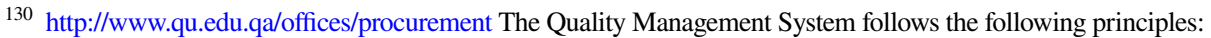
"Offer high standard of service by utilizing competent professionals, Increase the efficiency of employees and empower them by training, Focus on modernization and technology to increase operational efficiency, Closely interact with and monitor suppliers to establish highest quality standards, Achieve timely delivery as per specification and requirements, Attend and resolve complaints in a timely manner ensuring customer satisfaction, Progressively reduce customer complaints, Ensure continual improvement by setting and measuring objectives, carrying out regular quality audits, undertaking corrective and preventive action and conducting regular reviews by top management, Identify and address risks and take advantage of opportunities, Compliance with all legal, regulatory and contractual requirements". 
advancing a purchasing policy that encourages purchase of products and services that are environmentally friendly and do not cause harm to the environment ${ }^{131}$ and which are designed to minimize waste. ${ }^{132}$ Such policy will be consistent with Qatar 2030 vision which calls for enforcing international standards for environmental protection. ${ }^{133}$ A center for law and development ${ }^{134}$ was established at Qatar University focusing on research on climate change, water security, energy security, food security, land degradation, desertification, environmental factors contributing to armed conflict, environmental damage caused by armed conflict, environmental law, air pollution, air quality, and energy law.

Anti-Corruption Measures and Avoidance of Conflict of Interest: In taking the necessary measures to combat corruption, the University adopts regulations that ensure financial transparency and responsible purchasing practices. The general rules and procedures regarding university grants ensure avoidance of potential conflict of interests. They provide that "No employee of QU external or internal grant or contract should have any interest, financial or otherwise, direct or indirect, or engage in any business or transaction or professional activity or incur any obligation of any nature, which is in conflict with the proper discharge of his/her duties at QU." 135

Incorporating ethics in academic curricula: The College of law, for instance, offers courses that embody the university integrity rules, especially the newly established course on law clinics and the course on ethics of the legal professions. ${ }^{136}$ There is also a course on business ethics offered at the College of Buisness and Economics.

Intellectual Honesty: Qatar University faculty handbook expects from the faculty as researchers to "seek knowledge and truth, and must therefore uphold the highest standards of major and ethical standards and Judgment. They must at all times demonstrate intellectual honesty, and not permit other interests to compromise their freedom of inquiry." As teachers, they should encourage their students to learn and demonstrate "their respect for students by maintaining the appropriate roles as intellectual guides, advisors, and guardians of academic freedom. They facilitate and foster academic conduct, and evaluate student work in a fair and impartial way. They do not improperly exploit, harass or discriminate against students."137

Protection of Intellectual Property: The Intellectual Property Policy and Procedures of Qatar University provide for the ownership of the university of any and all intellectual

\footnotetext{
131 See e.g. The Environmental Policy of University of Warwick: https://warwick.ac.uk/about/environment/ warwick/policies/

132 See e.g. Environmental and Sustainability Policy of University of Sussex https://www.sussex.ac.uk/ webteam/gateway/file.php?name=environmental-policy-signed-22nd-june-2018.pdf\&site $=442$

133 As stated in Qatar vision 2030 "Qatar has already committed to enforcing international standards for environmental protection when designing and implementing its industrial projects. The country must also commit to making its future path of development compatible with the requirements of protecting and conserving the environment. Wherever there is an environmental cost to be paid for economic progress, it must be compensated with investments in technologies that help improve the environment".

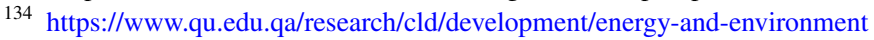

135 This policy provides for the following examples of cases of conflict of interest, "hiring relatives and associates, conflict with QU duties, engaging in any transaction with any business entity in which he/she has a direct or indirect financial interest, (and) using QU research or administrative facilities to pursue personal business or commercial consulting activities".

136 The College of Law also offers a specialized course on Combatting Corruption,

137 Qatar University Faculty handbook; Academic Bylaws, Faculty Senate Bylaws and the QU Academic Policies and Procedures (Spring 2012), http://www.qu.edu.qa/static_file/qu/Faculty\%20and\%20Staff/documents/QU_ Faculty_Handbook_June-Spring2012_EN.pdf
} 
property and inventions if they are conceived "utilizing university resources or other contributions of the university". However, the originator shall have the intellectual property rights if they are generated on his/her personal time and using personal resources, or if they are no longer with the university. ${ }^{138}$ Qatar University Authorship policy requires the main author or co- author to mention Qatar University as an affiliation in all academic work. Perhaps it is a good idea for Qatar University to consider adopting the WIPO Intellectual Property Policy Template for Universities and Research Institutions of 2019 which aims " to provide an IP policy, including ownership, incentives, confidentiality and publication, IP management and commercialization, recording and maintenance of IP, and IP-related conflicts of interest". ${ }^{139}$ The WIPO guide, as such, is designed to " ensure the legal protection, where applicable; effective management and commercialization of Institution IP; while at the same time not impeding with the traditions of education and scholarship, academic freedom, open and timely publications, institutional sovereignty, and the institution's mission serving the public interest". ${ }^{40}$

Policies, Regulations and Guidelines for Research Involving Humans: Qatar University Handbook for Ethical Rules and Regulations for Research Involving Human Subjects provides for the principle of respect for humans stating that " though the goal of science is to advance human health and welfare of all human beings, scientists should uphold the highest ethical standards that respect all living beings, with profound respect granted to human life and dignity." 141 These rules and regulations also provide for the principle of equitable selection of subjects, paying particular attention to "vulnerable populations, such as children, pregnant women, mentally disabled persons, or economically or educationally disadvantaged persons." 142 Their full and informed consent should be sought and they should be subject to special protection. All research on humans must be submitted to the Office of Academic Research ( OAR) which conducts a review of its scientific merits and to the Institutional Review Board (IRB) to decide whether it meets the ethical standards. Protection of human subjects in conducting research and practical work is the subject of detailed "Policies, Regulations and Guidelines for Research involving Human" that were issued by the Ministry of Public Health of the State of Qatar. ${ }^{143}$ In order to approve research covered by this policy, the Institutional Review Board (IRB) established thereunder must determine that risks to subjects are minimized, and that they are reasonable in relation to anticipated benefits. The Board must also determine that the selection of subjects is equitable, especially regarding "vulnerable populations, such as children, prisoners, pregnant women, mentally disabled persons or

\footnotetext{
138 To avoid any conflict of interest, the policy provides that "no member of the QU community shall patent or seek to patent inventions which are in the specific field of work in which the Originator is participating in a university research program without prior, written permission from the university." http:// www.qu.edu.qa/facultyandstaff/New-Faculty/Getting-Settled/Intellectual-Property-Policy-and-Procedures

139 WIPO Intellectual Property Policies for Universities, 2019, page 2.

140 Id. at p. 4.

141 Handbook forEthical Rules and Regulations forResearch Involving Human Subjects, Qatar University, article 1.4.

142 Id at article (2.1.1) para (3).

143 "Research" is defined for the purpose of these Policies, regulations and guidelines, as "a systematic investigation, including research development, testing and evaluation, designed to develop or contribute to general knowledge." https://www.moph.gov.qa/Admin/Lists/Services\%20Attachments/Attachments/31/Policies,\%20Regulations\% 20and\%20Guidelines\%20for\%20Research\%20Involving.pdf
} 
economically or educationally disadvantaged persons". ${ }^{144}$ The principles of informed consent $^{145}$ and protection of privacy are taken into consideration by the Board in making its decision to approve research that involves humans.

Professionalism of the Faculty: The Professional Conduct Policy of Qatar University defines professional misconduct to include "conflict of interest, research misconduct, breach of confidentiality and trust, misuse of university funds, equipment or facilities, breach of intellectual property, abuse of authority, defamation, harassment, conviction of crime, breach of professional ethics..." Under the professional conduct policy, research misconduct includes "fabrication, falsification, or plagiarism in proposing, performing, or reviewing research, or in reporting research results". The "Faculty Consultancy Policy" grants faculty members the privilege of consulting based on a belief "in the enriching interaction of faculty members with industry, business, government, and other activities and institutions of (the Qatari) society" Therefore such consultancy is recognized in the annual appraisal of the faculty member when evaluating the extent of his/her service to the community. However, before entering into a consultancy agreement, the faculty member "must determine that the contemplated consultancy activities and arrangements will not involve a conflict of interest, misuse of university resources or name, infringement of intellectual property and /or unauthorized disclosure of confidential information related to University activities". The professional Conduct Policy defines "harassment" as a form of "professional misconduct; "in which individuals face discriminatory behaviors based on race, age, gender, nationality, or religion." It further states that "Harassing behavior includes verbal, written or physical conduct directed against another that is abusive, intimidating, humiliating, or generally impairs the opportunity to conduct work".

Students Code of Conduct: Qatar University Code of Conduct expects a student "not to engage in behaviors that compromise their integrity, as well as the integrity of QU." Academic violations under the Code are divided into three categories that include inappropriate collaboration, ${ }^{146}$ dishonesty $^{147}$ and intellectual property

\footnotetext{
144 For the application of this principle to victims of human trafficking see general, Mattar, M. Y. (2017). Medical liability for trafficking in persons for the purpose of human experimentation: international standards and comparative models from Arab jurisdictions. International Annals of Criminology, 55(1), 4-25.

${ }^{145}$ The Policies, Regulations and Guidelines provide for detailed requirement of what is considered as "informed consent". https://www.qu.edu.qa/static_file/qu/research/documents/qu_irb/QU-IRB\%20Handbook\% 20-\%20Ethical\%20Rules\%20and\%20Regulations.pdf

146 Inappropriate collaboration includes "working with someone else in developing, organizing or revising a submitted work without acknowledging that person's help. This work may include: projects, papers, oral presentations, research, design projects or take-home examinations, use of tutors for writing, editing or producing a submitted work and the use of unauthorized assistance in all cases of submitted work." http://www.qu.edu. qa/students/code-of-conduct.

147 Dishonesty includes "cheating or any attempt of cheating or disruption during testing sessions Dishonesty in examinations or any submitted work may include the following forms: 1- submissions of non-original papers, test results, work and materials; 2- any form of communication between or among students during examination; 4- cheating from another student during examination; 4- copying from another's paper. Giving unauthorized assistance, 5- obtaining unauthorized advance knowledge of examination questions, through the use of mobiles or other electronic devices, 6- obtaining false scores on machine-graded examinations, and 7- submitting any material prepared by or purchased from another person or company including reports and research papers." http://www.qu.edu.qa/students/code-of-conduct
} 
violations ${ }^{148}$ or plagiarism. ${ }^{149}$ The Code of Conduct also provides for a number of non-academic violations including "harassment (verbal or physical) and/or intimidation of peers, faculty, and university visitors and employees in person or through channels of social media or emails, and using any social media channel to defame QU or posting pictures of any of the QU staff, faculty members, or students without their consent."

With the increasing use of social media outlets, a more detailed social media policy is needed. prohibiting "unlawful, defamatory, obscene posting"" on the rights or privacy of other students or staff" 151 or that reveal "confidential or proprietary information about the university students, employees or alumni" 152 or do not "respect copyright and fair use" 153 Information posted on social media channels must be "accurate and factual" 154 with the intent to "communicate and build relationships", 155 "accelerate teaching and learning"" 156 and "enjoy the benefits of social networking". ${ }^{157}$ Otherwise, use of the social medial would negatively affect the university and grossly harm its reputation.

The Code of Conduct also provides for violation of QU dress code stating that the University "recognizes cultural diversity and respects the requirements needed for a productive learning environment. Students, both males and females, are expected to dress in a manner respectful of the local Qatari culture and traditions as well as the academic nature of the institutions. Inappropriate dress for both males and females is unacceptable."158 The Code of Conduct may apply to acts that are committed outside the university if the student is attending an off-campus event as a representative of the university such as in conferences, athletic events or other similar events.

Academic disputes ${ }^{159}$ are subject to detailed procedures that are designed to ensure that the student is being treated fairly and properly. According to these procedures, disputes are

\footnotetext{
148 As stated in the Code of Conduct "Respect for original intellectual creativity is vital at academic discourse. This principle applies to works of all authors and publishers in all forms. This encompasses respect for the right to acknowledgment, the right to privacy and the right to determine the form, manner and terms of publication and distribution." http://www.qu.edu.qa/students/code-of-conduct

149 The Code of Conduct explains that plagiarism applies to all student assignments or submitted work and it includes the use of the work, ideas, images or words of someone without his/her permission, use of someone else's words, name, phrase, sentence, paragraph, or essay without referring to the source, and misrepresentation of the sources that were used." http://www.qu.edu.qa/students/code-of-conduct

150 Consider for instance the social media policy of University of Houston. https://uh.edu/marcom/guidelinespolicies/social-media/

151 See the social media policy for students at University of Nottingham. https://www.nottingham.ac.uk/ currentstudents/student-charter/student-community/social-media-policy.aspx

152 See Social Media Policy of University of Dallas: https://udallas.edu/offices/communications/social/ social-policy.php

153 See Social Media Policy of University of Dallas: https://udallas.edu/offices/communications/social/ social-policy.php

154 See Manchester University Social Media Policy: http://documents.manchester.ac.uk/display.aspx?DocID= 42150

155 Id.

$156 \mathrm{Id}$.

157 See University of Exeter Social Media Policy for Employees: https://www.exeter.ac.uk/staff/employment/ hrpoliciesatoz/socialmedia/

158 See Federation University of Australia Social Media Policy: https://policy.federation.edu.au/university/ general/socialmedia/ch01.php

159 QU Code of Conduct defines academic disputes to include "admission, grades during the academic semester, academic suspension, and charges of dishonesty, plagiarism, deliberate forgery of data, work completed for one course and submitted for another, and violation of intellectual property. http://www.qu. edu.qa/students/code-of-conduct
} 
to be informally resolved through discussions of the grievances between the student and the faculty member, the department head, or the college dean, before they may be subject to formal complaint by the student. In the meantime, the disciplinary actions vary based on the seriousness of the academic or non-academic violation. ${ }^{160}$ Non-academic violations that include threats to the lives of others, verbal or physical harassment, and invasion of privacy or theft are also subject to serious disciplinary actions that may reach expulsion from the university. ${ }^{161}$ Establishing legal liability for academic corruption or dishonesty may be based on several legal theories. For instance, contract cheating may amount to a claim of false advertisement. ${ }^{162}$ It has been proposed that a new 'offence to provide or advertise cheating services' should offer the legal solution in cases of contract cheating ${ }^{163}$ when students employ or use a third party to undertake their assessed work for them.

\section{Conclusion}

This article has shown that existing research on academic integrity mainly focuses on student cheating and faculty plagiarism and that most of this research covers regions other than the Arab region. The article also concluded that while academic integrity is a major indicator in granting academic accreditation, accrediting agencies do not always inquire into whether an academic institution has an explicit and comprehensive policy on academic integrity.

Academic integrity, in this article, is broadly defined to include, not only students cheating or faculty plagiarism, but also any act that is in violation of rules that are designed to promote independence, autonomy and transparency. It also means academic freedom and academic honesty. Academic institutions should adopt policies that are designed to enhance access to higher education without discrimination. They should put in place policies that ensure professionalism and enhance intellectual excellence. These standards should constitute the foundation for international accreditation. Accrediting agencies should explicitly require strict adherence to these standard, inquiring into the role of an academic institution in providing community services and making contributions beyond teaching and research. More importantly, as this article has argued, accrediting agencies should explicitly ask academic institutions for specific policies that promote academic integrity and combat academic corruption.

As indicated, Qatar University adopts policies that are designed to combat academic corruption and enhance academic integrity. These policies cover a variety of issues

\footnotetext{
160 "In cases of impersonation, deliberate labefaction of data, complicity of academic dishonesty and intellectual property violations or plagiarism, the student may be warned in writing, suspended for two consecutive terms, expelled from the university, temporary suspended of granting the academic degree, or subject to cancellation of the Academic degree granting decision in case of fraud in the documents or procedures that led to granting the degree." http://www.qu.edu.qa/students/code-of-conduct

161 QU Code of Conduct is clear in expecting its students "to behave in a way that respects the norms and social behavior of the Qatari society and the Academic environment of its premises that mandates segregation. Violations of this respect of norms include as well inappropriate behavior including verbal or physical harassment in addition to invading the privacy of others in all its form within the confines of the QU campus.” http://www.qu.edu.qa/students/code-of-conduct

162 See Draper, M. J., \& Newton, P. M. (2017). A legal approach to tackling contract cheating?. International Journal for Educational Integrity, 13(1), 11.

163 The Proposal for the "offence to provide or advertise cheating services" https://publications.parliament. uk/pa/bills/lbill/2016-2017/0097/17097-III.pdf
} 
including; corporate social responsibility standards, human rights policies, non discrimination in admissions, labor rights, verification of recruitment, an environmental policy, anti corruption measures and avoidance of conflict of interest, incorporating ethics in educational curricula, intellectual honesty, protection of intellectual property, policies, regulations and guidelines for research involving humans, professionalism of the faculty and students code of conduct.

I argued for more explicit and comprehensive polices that embody the main principles of human rights, corporate social responsibility, environmental standards and anti-corruption measures, all of which have been referenced in the different guidelines and regulations issued by the University. I also argued for a more detailed social media policy, a specific anti-radicalization and extremism policy and a special policy on the protection of students underage.

With the absence of a credible regional accreditation agency in the Arab region, the similarities of the educational systems in almost every discipline of learning and the real need to monitor and review the performance of Arab academic institutions, Qatar University's policies may serve as a model to be considered by other Arab universities.

Whether University policies and procedures embodied in handbooks, codes of conduct, and guides are enforceable should not be subject to debate or conflict. When a faculty member signs an employment contract or accepts an offer of employment, additional information provided in these documents may constitute a part of the contract and thus further determines its content including the rights and obligations stipulated thereunder. So should the University employment contract make a specific reference to these policies and procedures? And should these policies and procedures explicitly state their binding effect? A typical offer of employment at Qatar University explicitly states that "This offer is subject to the University policies and regulations and their amendments."

Open Access This article is licensed under a Creative Commons Attribution 4.0 International License, which permits use, sharing, adaptation, distribution and reproduction in any medium or format, as long as you give appropriate credit to the original author(s) and the source, provide a link to the Creative Commons licence, and indicate if changes were made. The images or other third party material in this article are included in the article's Creative Commons licence, unless indicated otherwise in a credit line to the material. If material is not included in the article's Creative Commons licence and your intended use is not permitted by statutory regulation or exceeds the permitted use, you will need to obtain permission directly from the copyright holder. To view a copy of this licence, visit http://creativecommons.org/licenses/by/4.0/.

\section{References}

Abusafia, A. H., Roslan, N. S., Yusoff, D. M., \& Nor, M. Z. M. (2018). Snapshot of academic dishonesty among Malaysian nursing students: A single university experience. Journal of Taibah University medical sciences, 13(4), 370-376.

Aljurf, S., Kemp, L., Williams, P. (2019). Exploring academic dishonesty in the Middle East: a qualitative analysis of students' perceptions. Studies in Higher Education, 1-13. https://doi.org/10.1080/ 03075079.2018.1564262

Alkhateeb, F. M., Arkle, S., McDonough, S. L. K., \& Latif, D. A. (2018). Review of National and International Accreditation of Pharmacy Programs in the Gulf Cooperation Council Countries. American Journal of Pharmaceutical Education, 82(10), 5980. https://doi.org/10.5688/ajpe5980

Alogali, A. (2015). Innovation with Integrity: Exploring Academic Honesty and Intellectual Property in the Middle East. In WEI International Academic Conference proceedings. University Affiliation: University of Rochester, Rochester NY, USA. https://www.westeastinstitute.com/wp-content/uploads/ 2015/07/Azizah-Alogali.pdf 
Ashour, S., \& Ghonim, A. S. (2017). The quest for regional accreditation of art and design education in the Arab countries. Cogent Arts \& Humanities, 4(1), 1361639. https://doi.org/10.1080/23311983.2017. 1361639

Ayala-Enríquez, P., Franco-Pérez, N., Guerrero-Dib, J. G., \& Pizarro-Puccio, G. (2020). "From moral awareness to academic integrity in Latin America". In A Research Agenda for Academic Integrity. Cheltenham, UK: Edward Elgar Publishing. https://doi.org/10.4337/9781789903775.00009

Badran, A., Baydoun, E., \& Hillman, J. R. (Eds.). (2019). Major challenges facing higher education in the Arab world: Quality assurance and relevance. Springer.

Cinali, G. (2016) Middle Eastern Perspectives of Academic Integrity: A View from the Gulf Region. In: Bretag T. (eds) Handbook of Academic Integrity. Springer, Singapore. https://doi. org/10.1007/978-981-287-098-8_8

Curaj, A., Deca, L., \& Pricopie, R. (2018). European higher education area: The impact of past and future policies (p. 721). Springer Nature.

Denisova-Schmidt, E. (Eds.). (2020). Corruption in Higher Education. Leiden, The Netherlands: Brill । Sense. https://doi.org/10.1163/9789004433885

Denisova-Schmidt, E. (2020). Corruption in Higher Education. Leiden, The Netherlands: Brill I Sense. https:// doi.org/10.1163/9789004433885

Dimkpa, D. I. (2011). Prevalence, causes and effects of academic corruption in Rivers State Universities. Nigeria. Makerere Journal of Higher Education, 3(1), 33-44.

Dodeen, Hamzeh M. (2012). Undergraduate Student Cheating in Exams. Damascus University Journal, 28(1).

Draper, M. J., \& Newton, P. M. (2017). A legal approach to tackling contract cheating? International Journal for Educational Integrity, 13(1), 11.

Eaton, J. S. (2020). "Combatting Academic Corruption". In Corruption in Higher Education. Leiden, The Netherlands: Brill I Sense. https://doi.org/10.1163/9789004433885_026

Elshobaky, Amel. (2005). Distance Higher Education in the Arab Region: The Need for Quality Assurance Frameworks. Online Journal of Distance Learning Administration, 8.

Faek, R. (2017). How Arab Countries Regulate Quality in Higher Education. https://www.chronicle.com/ article/how-arab-countries-regulate-quality-in-higher-education/

Feday, S. W. (2017). Academic dishonesty in Ethiopian higher education and its implication for corruption. Beijing L. Rev., 8, 10.

Foltýnek, T., \& Dlabolová, D. (2020). "Academic integrity in Eastern Europe: beyond corruption and plagiarism". In A Research Agenda for Academic Integrity. Cheltenham, UK: Edward Elgar Publishing. https://doi.org/10.4337/9781789903775.00010

GANI, A. (2009). Quality Assurance of the Arab Open University in Saudi Arabia. Asian Journal of Distance Education, 7(2).

Glendinning, I. (2020). "The role of quality assurance and regulatory organizations to promote academic integrity," Chapters, in: Tracey Bretag (ed.), A Research Agenda for Academic Integrity (chapter 2, pp. 13-2). Edward Elgar Publishing.

Griffith, J. (2013). Pedagogical over Punitive: The Academic Integrity Websites of Ontario Universities. Canadian journal of higher education, 43(1), 1-22.

Hamdatu, M. A. M., Siddiek, A. G., \& Rahman Al-Olyan, F. A. (2013). Application of Quality Assurance \& Accreditation in the Institutes of Higher Education in the Arab World (Descriptive \& Analytical Survey)

Harkavy, I. (2006). The role of universities in advancing citizenship and social justice in the 21 st century. Education, citizenship and social justice, 1(1), 5-37.

Khan, Z., \& Subramanian, S. (2012). Students go click, flick and cheat... e-cheating, technologies and more. Journal of Academic and Business Ethics, 6, 1-26.

Klemenčič, M. (2019). 20 Years of the Bologna Process in a Global Setting: the external dimension of the Bologna Process revisited.

Lynch, S. (2015). A Growing Number of Arab Universities Seek International Accreditation. https://www. al-fanarmedia.org/2015/03/a-growing-number-of-arab-universities-seek-international-accreditation/

Marzouk, O. (2019). Status of ABET Accreditation in the Arab World. Global Journal of Educational Studies, 5, 1. https://doi.org/10.5296/gjes.v5i1.14218

Mattar, M. Y. (2013). Article 43 of the Arab charter on human rights: reconciling national, regional, and international standards. Harvard Human Rights Journal, 26, 91-147.

Mattar, M. Y. (2017). Medical liability for trafficking in persons for the purpose of human experimentation: international standards and comparative models from Arab jurisdictions. International Annals of Criminology, 55(1), 4-25. 
McCabe, D. L., Feghali, T., \& Abdallah, H. (2008). Academic Dishonesty in the Middle East: Individual and Contextual Factors. Research in Higher Education, 49, 451-467. https://doi.org/10.1007/s11162008-9092-9

Nabaho, L., \& Turyasingura, W. (2019). Battling Academic Corruption in Higher Education: Does External Quality Assurance (EQA) Offer a Ray of Hope? Higher Learning Research Communications, 9(1), 2.

Namagembe, S., \& Ntayi, J. M. (2012). Ethical sensitivity, academic dishonesty and career growth of academic staff in institutions of higher learning in Uganda. International Journal of Economics and Management Sciences, 1(8), 56-63.

Osipian, A. L. (2007). Corruption in higher education: Conceptual approaches and measurement techniques. Research in Comparative and International Education, 2(4), 313-332.

Plackett, B., \& Wachter, S. (2019). An Arab Student's Guide to Higher-Education Accreditation. https:// www.al-fanarmedia.org/2019/06/an-arab-students-guide-to-higher-education-accreditation/

Qatar Supreme Court, Civil and Commercial circuit. (2012). Case No. 81

Razek, N. (2014). Academic integrity: A Saudi student perspective. Academy of Educational Leadership Journal, 18(1).

Reisberg, L. (2020). "Challenges to Eradicating Academic Corruption". In Corruption in Higher Education. Leiden, The Netherlands: Brill I Sense. https://doi.org/10.1163/9789004433885_027

Vincent, J. (2008). Corruption in Education: A Global Legal Challenge. Santa Clara Law Review, 48. Available at SSRN: https://ssrn.com/abstract=2891900

Wilkens, K. (2011). Higher Education Reform in the Arab World.

\section{Secondary Sources}

Accreditation Board for Engineering and Technology. https://www.abet.org/accreditation/

Arab Organization for Quality Assurance. http://aroqa.org/en

Asia Pacific Quality Network. https://www.apqn.org/

Association for Education in Journalism and Mass Communication. http://www.acejmc.org/

Association to Advance Collegiate Schools of Business. https://www.aacsb.edu/accreditation/standards\#gsc. $\mathrm{tab}=0$

British Accreditation Council. https://www.the-bac.org/

Canadian Council for Accreditation in Pharmacy Programs. http://ccapp-accredit.ca/

Certified Health Education Specialist. http://ches.info/accreditation.html

Childhood Education International https://acei.org/

Code of Academic Integrity, Aurora University, Illinois, U.S. https://www.aurora.edu/academics/resources/ code.html

Code of Conduct, Georgia State University. https://codeofconduct.gsu.edu/

Code of Student Rights, Responsibilities and Conduct, Indiana University. https://studentcode.iu.edu/?_ ga=2.66081709.2018066908.1591548928-1456551481.1591548928

Council for Higher Education Accreditation. https://www.chea.org/

Environmental and Sustainability Policy of University of Sussex. https://www.sussex.ac.uk/webteam/ gateway/file.php?name=environmental-policy-signed-22nd-june-2018.pdf \&site $=442$

Ethical Principles and Professional Practice Standards for Special Educators. https://www.cec.sped.org/

European University Association. https://eua.eu/

Faculty Performance Review and Development System Guidelines \& Policies. https://www.qu.edu.qa/ static_file/qu/offices\%20and\%20departments/VPAA/documents/ACADEMIC_029_QU_Faculty_ Performance_Review_and_Development_System_EMC_Approved_V01_Sep17_2014.pdf

Federation University of Australia Social Media Policy: https://policy.federation.edu.au/university/general/ socialmedia/ch01.php

Foundation for International Business Administration Accreditation. https://www.fibaa.org/en/welcomepage.html

High Council for Evaluation of Research and Higher Education. https://www.hceres.fr/en

https://www.topuniversities.com/asia-rankings/methodology

International Network for Quality Assurance Agencies. https://www.inqaahe.org/

Judicial Standards of a Legal Education. https://www.ialsnet.org/wp-content/uploads/2017/12/Judicial-Standardsof-a-Legal-Education.pdf

Law Clinic at Qatar University College of Law. https://www.qu.edu.qa/law/departments/legal-skills/law-clinic Madrid Protocol. https://www.ialsnet.org/wp-content/uploads/2016/05/Madrid-Protocol-Final.pdf

Manchester University Social Media Policy: http://documents.manchester.ac.uk/display.aspx?DocID=42150 
National Accrediting Agency for Clinical Laboratory Sciences https://www.naacls.org/about.aspx

National Association for the Education of Young Childrenhttps://www.naeyc.org/

National Council for Accreditation of Teacher Education http://www.ncate.org/

Qatar University Academic Recruitement Guide https://www.qu.edu.qa/static_file/qu/offices\%20and\% 20departments/VPAA/documents/vpaa_academic_recruitment_guide_vpcao_fall_2010.pdf

Qatar University Code of Conduct http://www.qu.edu.qa/students/code-of-conduct

Qatar University Faculty handbook; Academic Bylaws, Faculty Senate Bylaws and the QU Academic Policies and Procedures (Spring 2012). http://www.qu.edu.qa/static_file/qu/Faculty\%20and\%20Staff/ documents/QU_Faculty_Handbook_June-Spring2012_EN.pdf

Qatar University human resources strategy and work plan. https://www.qu.edu.qa/static_file/qu/offices\% 20and\%20departments/Human\%20resources/documents/Human_Resources_Strategy_and_Work_Plan. pdf

Qatar University Intellectual Property Policy and Procedures. http://www.qu.edu.qa/facultyandstaff/NewFaculty/Getting-Settled/Intellectual-Property-Policy-and-Procedures

Qatar University Strategy. http://www.qu.edu.qa/file_source/qu/about/documents/Qatar\%20University\% 20Strategy\%202018-2022\%20Booklet\%20-\%20EN.pdf

Rethinking education: towards a global common good? https://unesdoc.unesco.org/ark:/48223/pf0000249460/ PDF/249460eng.pdf.multi

Ryerson University "Discrimination and harassment prevention policy". https:/www.ryerson.ca/policies/ policy-list/dhppolicy/\#: :text=Ryerson\%20University’s\%20Discrimination\%20and\%20Harassment\% 20Prevention\%20Policy\%20and\%20Procedures\%20are,and\%20facilitative $\% 20$ for $\% 20$ all $\% 20$ parties

Simon Fraser University "Human Rights Policy". https://www.sfu.ca/policies/gazette/general/gp18.html\#: : text=Simon\%20Fraser\%20University\%20promotes\%20teaching,and $\% 20$ critical $\% 20 \mathrm{discussion} \% 20 \mathrm{of} \%$ 20ideas.\&text=Discrimination $\% 20$ undermines $\% 20$ these $\% 20$ objectives $\% 2$ C $\%$ 20violates, remedial\% 20action $\% 20$ by $\% 20$ the $\% 20$ University

Singapore Declaration 2013. https://www.ialsnet.org/wp-content/uploads/2015/10/Singapore-Declaration-2013.pdf

Social media policy for students at University of Nottingham. https://www.nottingham.ac.uk/currentstudents/ student-charter/student-community/social-media-policy.aspx

Social Media Policy of University of Dallas: https://udallas.edu/offices/communications/social/social-policy.php

Social media policy of University of Houston. https://uh.edu/marcom/guidelines-policies/social-media/

Standards and Guidelines for Quality Assurance in the European Higher Education Area (ESG), (2015). https://enqa.eu/index.php/home/esg/.

The American Bar Association. https:/www.americanbar.org/content/dam/aba/administrative/legal_education_ and_admissions_to_the_bar/standards/2019-2020/2019-2020-aba-standards-chapter2.pdf

The Council for Higher Education Accreditation (CHEA). https://www.chea.org/

The Environmental Policy of University of Warwick: https://warwick.ac.uk/about/environment/warwick/ policies/

The Institution of Environmental Sciences. https://www.the-ies.org/

The International Association of Law Schools [IALS]. https://www.ialsnet.org/charter-bylaws/

The Royal Statistical Society. https://rss.org.uk/

Times Higher Education University Rankings. https://www.timeshighereducation.com/world-universityrankings/world-university-rankings-2020-methodology

Union of International Associations. https://uia.org/

United Nations Academic Impact. https://academicimpact.un.org/content/about-unai

University of Exeter Social Media Policy for Employees: https://www.exeter.ac.uk/staff/employment/ hrpoliciesatoz/socialmedia/

University of Guelph "Human Rights Policy." https://www.uoguelph.ca/diversity-human-rights/sites/ default/files/Human\%20Rights\%20Policy_0.pdf

Publisher's Note Springer Nature remains neutral with regard to jurisdictional claims in published maps and institutional affiliations. 